Historic, Archive Document

Do not assume content reflects current scientific knowledge, policies, or practices. 



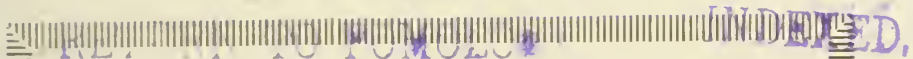

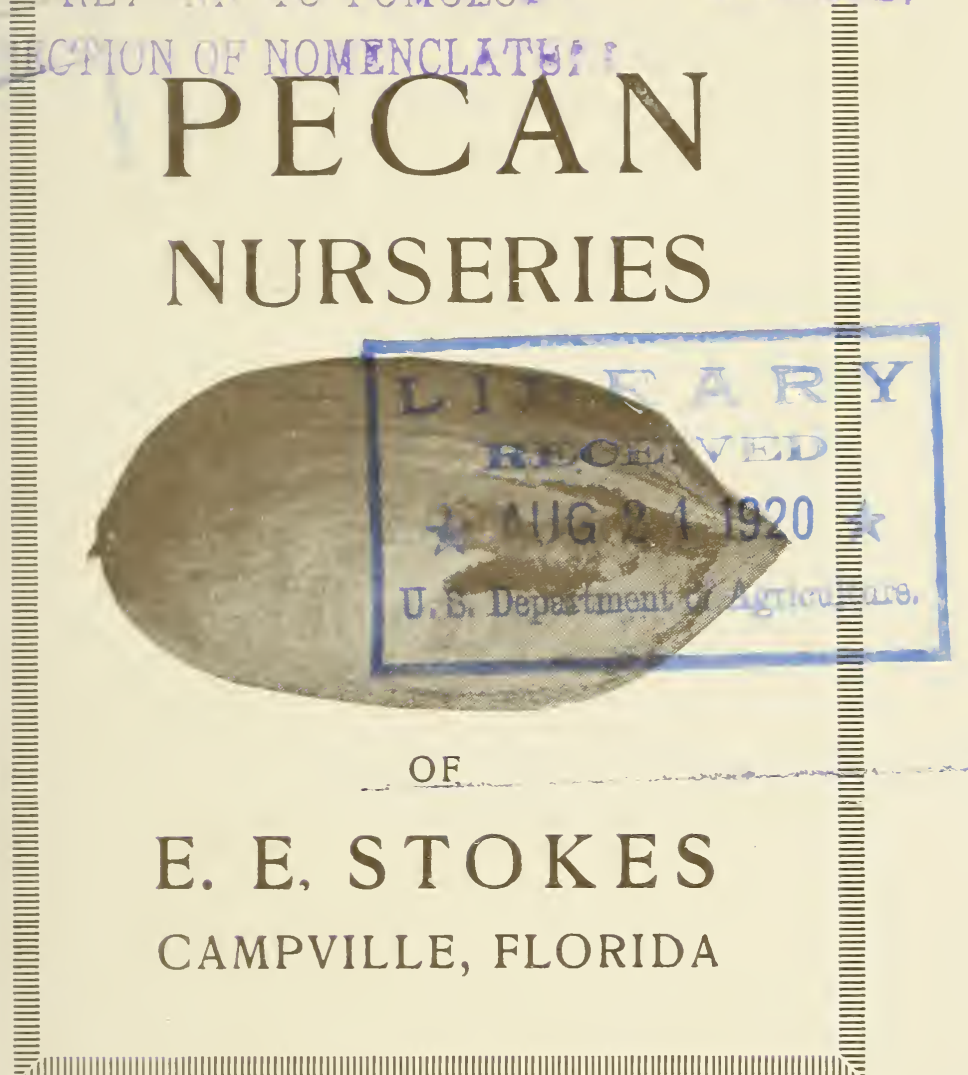

言南|||||||||||||||||||||||||||||||||||||||||||||||||||||||||||||||||||||||||||||||||||||||||||||||||||||||||||||||||||||||||||||

\section{MONEY IN PECANS}

7 HE PECAN has now become thoroughly established as one of the leading commercial orchard trees. They are hardy and long-lived trees. While naturally a forest tree, it responds to extra good care as other fruit trees.

Land set to pecan trees increases in value every year.

Good varieties of pecan trees grown on stock from large improved nuts make a wise investment. 
In sending out this price list for the winter of 1916 and 1917, am pleased to inform the trade that I have more trees for sale than any previous winter, and I believe as good trees as can be grown. They are budded on stock grown from large improved nuts, which have a great advantage over trees grown on stock from small pecans. Every one who plants pecan trees ought to know this. I find that trees budded on stock grown from large improved nuts grow faster and develop into large strong trees more quickly.

I give my pecan nurseries my personal attention. I select buds from good bearing wood, so that my trees will give my customers the very best service possible. I have cut out such varieties as do not seem to be well adapted to the South.

I make a specialty of growing and budding pecans, being engaged in this industry for the past twelve years.

CURTIS. Size medium, shell thin, kernel plump, flavor rich and of excellent quality. It is very productive, being well adapted to the South; has more good qualities than any variety I have tried.

PRESIDENT. Bright yellowish brown with a few broken stripes near apex; size 45 to 50 to the $1 \mathrm{~b}$.; shell thin, cracking easily; very attractive, fine flavor, very prolific.

VAN DEMAN One of the finest nuts yet introduced; always brings good prices.

SCHLEY Large size, about $1 \frac{7}{8}$ by $\frac{7}{8}$ inch; oblong, light reddish brown, specked at base; shell thin, brittle, cracking quality excellen1; kernel plump, smooth, full; flavor rich and sweet. A good grower and said to be a heavy bearer. 
STUART. An old and well tried Triety. I believe it has been recommended by the government.

TECHE Size medium to large; color grayish brown with a few dark streaks; base and apex round; shell thin, cracking easily; quality good; very prolific; comes into bearing very early.

RUSSELL. Best adapted to the South; nut medium to large in size, someyhat pointed at both ends; shell very thin; quality good; bears large and regular crops.

KENNEDY. This variety came from the same lot of seed as that of the famous Curtis variety. Size larger than the Curtis. Tree strong and healthy grower, early and abundant bearer; quality the best.

RANDALL. Nut medium to large, grayish brown, kernel plump, full, comes out of shell whole; has nutty flavor; quality good; heaviest bearer I know of.

DELMAS. Size large ovate; color dark gray, marked with dark specks and streaks; shell medium thick, cracking quality good; kernel bright yellow; flavor sweet; quality good; very early bearer.

\section{Prices on Budded Pecans:}

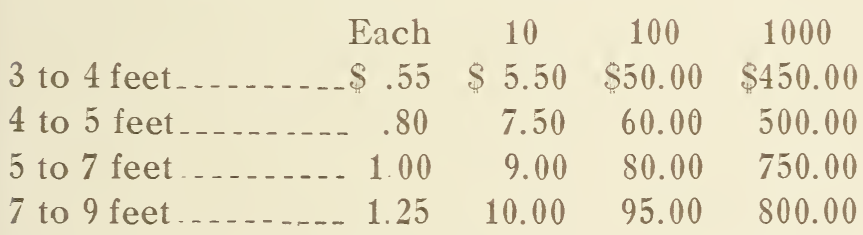

I also handle peach and citrus and all kinds of fruit trees adapted to this climate.

My long experience in growing fruit trees in this State enables me to select for my customers such as will give them the best service. 


\section{TERMS OF BUSINESS}

Shipping season from November to March 1st.

I substitute when not otherwise instructed.

Terms cash.

If an error should occur and same be reported to me promptly, I will correct same or refund purchase price.

When trees are delivered to transportation company in good order my responsibility ceases.

Trees baled or boxed carefully.

Come and see my nurseries and groves, showing what can be done when good trees are planted.

Instructions how to plant and care for trees go with each order.

I have bought a great many pecan trees from E. E. Stokes. I find him to be a good pecan nurseryman. He plants large improved nuts to grow stock on which he buds his trees. I find that pecan trees grown on stock from large improved nuts grow faster and make better trees than those grown on stock from small nuts.

$$
\begin{aligned}
& \text { P. H. BAKER, } \\
& \text { Turpentine Operator, }
\end{aligned}
$$
Campville, Fla.

\section{Danville, Ill., Oct. 17, 1916.}

To Any One Interested in PeCAN Trees:

Permit me to state that during the past five years I have purchased approximately 2,000 budded and grafted pecan trees from Mr. E. E. Stokes of Campville, Fla. I purchased different sized trees and after four years of growth the largest trees produced a few nuts. I now have 150 trees bearing nuts after only five years of growth and can readily recommend the trees that Mr. Stokes produces, both as to quality and size. I consider that Mr. Stokes has as fine a quality of pecan trees as can be obtained in the territory that he represents.

Very respectfully yours, HENRY BiRELINE.

Mr. E. E. STOKes:

$$
\text { WALDO, FLA., Oct. 19, } 1916 .
$$

Dear Sir: The pecan trees I got from you last year all lived and made an excellent growth, although some of them were planted out late. I have seen other trees sold by you to my neighbors and have been impressed by their healthy, vigorous appearance. I expect to give you a large order this year.

S. M. GODBEy. 